\title{
High miR-24 expression is associated with risk of relapse and poor survival in acute leukemia
}

\author{
JORGE ORGANISTA-NAVA $^{1 *}$, YAZMÍN GÓMEZ-GÓMEZ ${ }^{2 *}$, BERENICE ILLADES-AGUIAR ${ }^{3}$, \\ LUZ DEL CARMEN ALARCÓN-ROMERO ${ }^{4}$, MÓNICA VIRGINIA SAAVEDRA-HERRERA ${ }^{2}$, \\ ANA BERTHA RIVERA-RAMÍREZ ${ }^{2}$, VÍCTOR HUGO GARZÓN-BARRIENTOS ${ }^{2}$ \\ and MARCO ANTONIO LEYVA-VÁZQUEZ ${ }^{3 *}$
}

\author{
${ }^{1}$ Institute of Cellular Physiology, National Autonomous University of Mexico (UNAM), University City, D.F.; \\ ${ }^{2}$ Research Department, State Cancer Institute, 'Arturo Beltran Ortega', Acapulco, Guerrero; \\ Laboratories of ${ }^{3}$ Molecular Biomedicine and ${ }^{4}$ Cytopathology, School of Chemical- \\ Biological Sciences, Guerrero State University, Chilpancingo, Guerrero, Mexico
}

Received December 3, 2014; Accepted January 21, 2015

DOI: $10.3892 /$ or.2015.3787

\begin{abstract}
MicroRNAs (miRNAs) play an essential role in the development and progression of acute leukemia (AL). miR-24 promotes the survival of hematopoietic cells. However, little is known concerning the function of miR-24 in human AL. The aim of the present study was to investigate the clinical significance of miR-24 expression in AL. miR-24 expression in 147 patients with AL and 100 healthy individuals was measured by quantitative reverse transcriptase-polymerase chain reaction (RT-qPCR). The results showed that compared with the healthy individuals, the expression of miR-24 in AL patients was significantly higher $(\mathrm{p}<0.001)$. In addition, miR-24 was expressed at significantly higher levels in acute myeloid leukemia (AML) patients and at significantly lower levels in acute lymphoblastic leukemia (ALL) $(\mathrm{p}<0.001)$. More importantly, Kaplan-Meier analysis showed that AL patients with high miR-24 expression tended to have shorter overall survival $(\mathrm{p}<0.05)$. In the multivariate analysis stratified for known prognostic variables, miR-24 was identified as an independent prognostic marker. Our data indicated that miR-24 upregulation was associated with poor prognosis in AL. miR-24 was identified for the first time as an independent marker for predicting the clinical outcome of AL patients.
\end{abstract}

Correspondence to: Dr Marco Antonio Leyva-Vázquez, Laboratory of Molecular Biomedicine, School of Biological Sciences, Guerrero State University, Av. Lázaro Cárdenas S/N, Ciudad Universitaria, Chilpancingo, Guerrero 39090, Mexico

E-mail: leyvamarco13@gmail.com

\section{*Contributed equally}

Key words: miR-24, acute leukemia, acute myeloid leukemia, acute lymphoblastic leukemia, prognosis in acute leukemia

\section{Introduction}

Acute leukemia (AL) is the most common cancer in childhood and is characterized by increased self-renewal of leukemia stem/progenitor cells, decreased cell death and a block in cell differentiation $(1,2)$. In Mexico it has been observed that of the two types of AL, acute lymphoblastic leukemia (ALL) shows the highest frequency, accounting for $85 \%$ of the cases, while acute myeloid leukemia (AML) constitutes 15\% (3).

MicroRNAs (miRNAs) are $22 \mathrm{nt}$, non-coding RNA molecules that play a role in most cellular processes, including apoptosis, cell differentiation, proliferation and survival pathways (4). Furthermore, cancer-specific miRNA profiles associated with diagnosis, staging, progression, prognosis and response to treatment have been identified in many types of cancers (5). In leukemia, miRNA expression signatures associated with the cytogenetic and clinical outcome of adult CLL, AML and Hodgkin lymphoma were have been reported (6-8).

Recently, it was observed that miRNAs play a major regulatory role in normal hematopoietic differentiation, evidenced by the discovery of a small set of hematopoietic stem-progenitor cell (HSPC)-expressed miRNAs (HE-miRNAs) which post-transcriptionally regulate specific mRNAs involved in hematopoiesis (9-11).

miR-24 was found to be enriched in CD34+ HSPCs (9), and has a well-defined role as a regulator of normal erythropoiesis via targeting of human activin receptor type 1, ALK4 (12). Additionally, miR-24 is implicated in regulating apoptosis and cell proliferation. Reported targets of miR-24 include proapoptotic (FAF-1, caspase 9, Bim and Apaf-1) and cell cycle proteins (13-15) and it was observed that miR-24 promotes the survival of hematopoietic cells (16).

Previous studies have identified the processes in which miR-24 is involved in hematopoietic cell lines. However, the number of studies on the miR-24 expression features and functions in samples from pediatric patients with AL is relatively low. In the present study, we investigated the expression of miR-24 in clinical samples from children with $\mathrm{AL}$, as well 
as healthy controls. Our primary aim was to investigate the differential expression of miR-24 in patients with AL and healthy individuals. Secondly, we determined if there was a significant association between miR-24 expression and patient survival, which could point to a potential role for miR-24 as a prognostic marker of AL.

\section{Materials and methods}

Study population. A case control study was carried out in the Pediatric Oncology Service of the State Cancer Institute (SCI) from the South of Mexico (Acapulco, Guerrero, Mexico), between September 2005 and July 2013. The cases consisted of 111 (ALL) and 36 (AML) patients diagnosed with AL, through bone marrow aspirate based on French-American-British morphological criteria of blast cells.

The diagnosis of ALL was further subclassified as T-lineage $\left(\mathrm{CD}^{+}, \mathrm{CD}^{+}\right.$plus $\mathrm{CD}^{+}$or $\mathrm{CD}^{+}$or both) or B-lineage $\left(\mathrm{CD} 22^{+}, \mathrm{CD}_{19}{ }^{+}, \mathrm{CD} 20^{+}, \mathrm{CD}^{2} \mathrm{~A}^{+}, \mathrm{HLA}^{-} \mathrm{DR}^{+}\right.$and $\mathrm{CD}^{+} 0^{+}$) (Becton-Dickinson Biosciences, Mountain View, CA, USA). The multiagent chemotherapeutic protocols used were 96091, 96092 or CIE-10:C9.1.0 of the Cancer Institute from Guerrero State and previously described $(17,18)$.

Immunophenotypic studies to myeloblastic leukemia showed HLA-DR ${ }^{+}, \mathrm{CD}_{13}{ }^{+}, \mathrm{CD}^{-}{ }^{-}, \mathrm{CD}_{33}{ }^{+}, \mathrm{CD} 45^{+}, \mathrm{CD} 34^{+}$ and $\mathrm{CD}_{117}$. Patients with AML were treated with cytarabine, mitoxantrone, daunorubicin and etoposide, according to the protocols of the Cancer Institute from Guerrero State (Tables I and II).

Complete remission was defined by $<5 \%$ blast cells in the bone marrow and normalization of the peripheral blood counts at 4 weeks after starting induction therapy. Relapse was defined as the reappearance of $>20 \%$ blast cells in the marrow, or the presence of localized leukemic infiltrates at any site after completion of induction chemotherapy $(17,19)$. The worst outcome was defined as a lack of response to induction therapy, a relapse after achieving complete remission or death due to any cause $(17,19)$. Overall survival (OS) was measured from the day of registration of the study until death from any cause, censored for patients known to be alive at the last contact. Risk classification was: standard risk, 1-10 years of age and presenting a white blood cell (WBC) count of $<50,000 / \mathrm{mm}^{3}$; high-risk, $<1$ and $>10$ years of age; and a WBC count $>50,000 /$ $\mathrm{mm}^{3}(17,20)$. The controls were 100 apparently healthy indi-

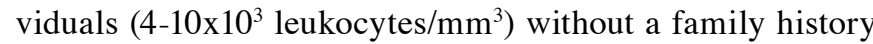
of leukemia. Subjects in both groups in the present study were 1-18 years of age, including both genders and were residents of the State of Guerrero, Mexico.

The bone marrow samples of the patients and blood samples of the healthy individuals used in the present study were part of the samples taken for clinical diagnostic tests in the hospital. No extra amount of samples was collected from the study subjects. Informed consent was obtained from all the individuals or their guardians, after a detailed briefing of the study aims. The present study and the informed consent procedure were approved by the Institutional Review Board of the Cancer Institute of the State of Guerrero, Mexico.

Specimen collection and total RNA extraction. A bone marrow and/or a blood sample were taken from the 247 participants and placed in tubes with anticoagulant. Leukocytes were purified from the whole blood sample by a selective osmotic lysis of erythrocytes (21); total RNA was extracted using the TRIzol method (Invitrogen, Carlsbad, CA, USA) according to the manufacturer's protocol and the quantity and concentration of RNA were spectrophotometrically assessed by measuring absorbance at A260/280.

Detection of translocations by polymerase chain reaction. Total RNA $(1 \mu \mathrm{g})$ was reverse transcribed into cDNA by priming with oligo(dT) and by the Superscript II First-Strand Synthesis System (Invitrogen) according to the manufacturer's instructions. After the synthesis of cDNA, translocations were detected by the molecular biology technique of conventional PCR. Specific primers were used in the PCR reaction to amplify BCR-ABL, ETV6-RUNX1, AML1-ETO and CBF $\beta$-MYH11 (22-26). The oligonucleotide sequences of these primers for each of these translocations are shown in Table III. Amplification was performed with a thermocycler Mastercycle ep gradient S (Eppendorf North America, Westbury, NY, USA).

For the amplification, cDNA $(10 \mu \mathrm{g})$ was brought to a final volume of $50 \mathrm{ml}$ with 1X PCR buffer, $0.2 \mathrm{mM}$ of each dNTP, $1.5 \mathrm{mM} \mathrm{MgCl} \mathrm{M}_{2}, 1 \mathrm{U}$ Taq polymerase (all from Invitrogen) and $0.4 \mu \mathrm{M}$ of each primer. For all the translocations and the constitutive gene, the conditions for amplification are shown in Table III using previously established protocols (22-26). The amplification products were subjected to electrophoresis on a $2.5 \%$ agarose gel, stained with ethidium bromide and viewed under an UV transilluminator. The amplification products could be discriminated by molecular size using a molecular weight marker (100 bp; Invitrogen).

Quantification of miRNAs using real-time PCR. To detect the levels of miR-24, 1-10 ng of total RNA was reverse transcribed to cmiRNA with specific RT primer using TaqMan ${ }^{\circledR}$ MicroRNA Reverse Transcription kit, and stem-loop real-time PCR was used to detect miR-24 level by the TaqMan ${ }^{\circledR}$ MicroRNA assays (000402) (both from Applied Biosystems, Foster City, CA, USA). The PCR cycles were as follows: $94^{\circ} \mathrm{C}$ for $5 \mathrm{~min}$, followed by 40 cycles of $94^{\circ} \mathrm{C}$ for $30 \mathrm{sec}, 60^{\circ} \mathrm{C}$ for $30 \mathrm{sec}$ and $72^{\circ} \mathrm{C}$ for $30 \mathrm{sec}$. Real-time reverse transcription polymerase chain reactions were performed in an Applied Biosystems 7500 Detection System (Applied Biosystems).

The expression of miR-24 was determined from the threshold cycle $(\mathrm{Ct})$, and the relative expression levels were calculated by the $2^{-\Delta \Delta \mathrm{Ct}}$ method. The $\mathrm{Ct}$ values were normalized with reference to the expression of RNU6B (001093; Applied Biosystems).

Statistical analysis. Continuous data are presented as the means \pm standard deviation (SD) or median, 25th and 75th interquartiles. Categorical data were compared by Chi-square or Fisher's exact tests. One-way analysis of variance (ANOVA) was used to compare differences among the miR-24 levels between groups, and results are presented as mean \pm SD. Univariate logistic regression analysis for the association with the risk of relapse to AL were tested first for miR-24 expression, gender and other clinical characteristics, and those factors were included into a second multivariate logistic analysis. The log-rank test 
Table I. Acute myeloid leukemia chemotherapy regimens.

\begin{tabular}{|c|c|c|}
\hline \multirow[t]{2}{*}{ Regimen } & \multicolumn{2}{|r|}{ Dosing } \\
\hline & \multicolumn{2}{|r|}{ High-risk patients } \\
\hline Induction therapy & Cycle 1 & \\
\hline Cytarabine & Days 1-7: & Cytarabine $100 \mathrm{mg} / \mathrm{m}^{2} /$ day continuous intravenous (IV) infusion for $2 \mathrm{~h}$ \\
\hline Daunorubicin & Days 1,3 and 5: & Daunorubicin $30 \mathrm{mg} / \mathrm{m}^{2} /$ day continuous IV infusion for $1 \mathrm{~h}$ \\
\hline Etoposide & Days 1-5: & Etoposide $100 \mathrm{mg} / \mathrm{m}^{2} /$ day IV for $3 \mathrm{~h}$ \\
\hline \multirow[t]{10}{*}{ Mitoxantrone } & Day 2: & Intrathecal (IT) chemotherapy (Table II) \\
\hline & Cycle 2 & \\
\hline & Days 1-7: & Cytarabine $100 \mathrm{mg} / \mathrm{m}^{2} /$ day continuous IV infusion for $2 \mathrm{~h}$ \\
\hline & Days 1, 3. 5: & Daunorubicin $30 \mathrm{mg} / \mathrm{m}^{2} /$ day continuous IV infusion for $1 \mathrm{~h}$ \\
\hline & Days 1-5: & Etoposide $100 \mathrm{mg} / \mathrm{m}^{2} /$ day continuous IV infusion for $3 \mathrm{~h}$ \\
\hline & Day 2: & IT chemotherapy (Table II) \\
\hline & Cycle 3 & \\
\hline & Days 1-5: & Cytarabine $100 \mathrm{mg} / \mathrm{m}^{2} /$ day continuous IV infusion for $2 \mathrm{~h}$ \\
\hline & Days 1-3: & Mitoxantrone $10 \mathrm{mg} / \mathrm{m}^{2} /$ day continuous IV infusion for $30 \mathrm{~min}$ \\
\hline & Day 2: & Intrathecal (IT) chemotherapy (Table II) \\
\hline Maintenance therapy & Cycle 1 & \\
\hline Cytarabine & Days 1-3: & Cytarabine $1 \mathrm{~g} / \mathrm{m}^{2} /$ day continuous IV infusion for $2 \mathrm{~h}$ \\
\hline Daunorubicin & Days 1-3: & Mitoxantrone $10 \mathrm{mg} / \mathrm{m}^{2} /$ day continuous IV infusion for $30 \mathrm{~min}$ \\
\hline Etoposide & Day 2: & Intrathecal (IT) chemotherapy (Table II) \\
\hline \multirow[t]{11}{*}{ Mitoxantrone } & Cycle 2 & \\
\hline & Days 1-3: & Cytarabine $2 \mathrm{~g} / \mathrm{m}^{2} /$ day continuous IV infusion for $2 \mathrm{~h}$ \\
\hline & Days 1-4: & Etoposide $100 \mathrm{mg} / \mathrm{m}^{2} /$ day continuous IV infusion for $1 \mathrm{~h}$ \\
\hline & Day 2: & Intrathecal (IT) chemotherapy (Table II) \\
\hline & Cycle 3 & \\
\hline & Days 1-3: & Cytarabine $3 \mathrm{~g} / \mathrm{m}^{2} /$ day continuous IV infusion for $2 \mathrm{~h}$ \\
\hline & Cycle 4 & \\
\hline & Days 1-3: & Cytarabine $2 \mathrm{~g} / \mathrm{m}^{2} /$ day continuous IV infusion for $2 \mathrm{~h}$ \\
\hline & Days 1-4: & Etoposide $100 \mathrm{mg} / \mathrm{m}^{2} /$ day continuous IV infusion for $1 \mathrm{~h}$ \\
\hline & Day 2: & Intrathecal (IT) chemotherapy (Table II) \\
\hline & Low-risk patients & \\
\hline Induction therapy & Cycle 1 & \\
\hline Cytarabine & Days 1-7: & Cytarabine $100 \mathrm{mg} / \mathrm{m}^{2} /$ day continuous intravenous (IV) infusion for $2 \mathrm{~h}$ \\
\hline Daunorubicin & Days 1,3 and 5: & Daunorubicin $30 \mathrm{mg} / \mathrm{m}^{2} /$ day continuous IV infusion for $1 \mathrm{~h}$ \\
\hline \multirow[t]{6}{*}{ Etoposide } & Days 1-5: & Etoposide $100 \mathrm{mg} / \mathrm{m}^{2} /$ day IV for $3 \mathrm{~h}$ \\
\hline & Day 2: & Intrathecal (IT) chemotherapy (Table II) \\
\hline & Cycle 2 & \\
\hline & Days 1-7: & Cytarabine $100 \mathrm{mg} / \mathrm{m}^{2} /$ day continuous IV infusion for $2 \mathrm{~h}$ \\
\hline & Days 1,3 and 5: & Daunorubicin $30 \mathrm{mg} / \mathrm{m}^{2} /$ day continuous IV infusion for $1 \mathrm{~h}$ \\
\hline & Days 1-5: & Etoposide $100 \mathrm{mg} / \mathrm{m}^{2} /$ day continuous IV infusion for $3 \mathrm{~h}$ \\
\hline Maintenance therapy & Cycle 1 & \\
\hline Cytarabine & Days 1-3: & Cytarabine $1 \mathrm{~g} / \mathrm{m}^{2} /$ day continuous IV infusion for $2 \mathrm{~h}$ \\
\hline Daunorubicin & Days 1-3: & Daunorubicin $25 \mathrm{mg} / \mathrm{m}^{2} /$ day continuous IV infusion for $1 \mathrm{~h}$ \\
\hline \multirow[t]{8}{*}{ Etoposide } & Cycle 2 & \\
\hline & Days 1-3: & Cytarabine $1 \mathrm{~g} / \mathrm{m}^{2} /$ day continuous IV infusion for $2 \mathrm{~h}$ \\
\hline & Days 1-4: & Etoposide $100 \mathrm{mg} / \mathrm{m}^{2} /$ day continuous IV infusion for $1 \mathrm{~h}$ \\
\hline & Cycle 3 & \\
\hline & Days 1-3: & Cytarabine $2 \mathrm{~g} / \mathrm{m}^{2} /$ day continuous IV infusion for $2 \mathrm{~h}$ \\
\hline & Cycle 4 & \\
\hline & Days 1-3: & Cytarabine $1 \mathrm{~g} / \mathrm{m}^{2} /$ day continuous IV infusion for $2 \mathrm{~h}$ \\
\hline & Days 1-4: & Etoposide $100 \mathrm{mg} / \mathrm{m}^{2} /$ day continuous IV infusion for $1 \mathrm{~h}$ \\
\hline
\end{tabular}


Table II. Acute myeloid leukemia intrathecal (IT) chemotherapy.

\begin{tabular}{lcccc}
\hline Age (years) & Methotrexate $(\mathrm{mg})$ & Hydrocortisone $(\mathrm{mg})$ & ARA-C $(\mathrm{mg})$ & Volume $(\mathrm{ml})$ \\
\hline$<2$ & 8 & 16 & 24 & 8 \\
2 & 10 & 20 & 30 & 10 \\
$>3$ & 12 & 24 & 36 & 12 \\
\hline
\end{tabular}

Table III. Oligonucleotide sequences of the primers used in this study.

\begin{tabular}{|c|c|c|c|}
\hline Genetic fusion & Sense strand & Antisense strand & Size (bp) \\
\hline \multicolumn{4}{|l|}{ BCR-ABL } \\
\hline Subtype b3a2 & 5'-TCGTGTGTGAAACTCCAGAC-3' & 5'-CCATTCCCCATTGTGATTAT-3' & 349 \\
\hline Subtype b2a2 & 5'-TCGTGTGTGAAACTCCAGAC-3' & 5'-CCATTCCCCATTGTGATTAT-3' & 274 \\
\hline Subtype e1a2 & 5'-ACTGCCCGGTTGTCGTGT-3' & 5'-CCATTCCCCATTGTGATTAT-3' & 317 \\
\hline $\begin{array}{l}\text { Internal control } \\
\mathrm{ABL}\end{array}$ & 5'-TAGCATCTGACTTTGAGCCT-3' & 5'-CCATTCCCCATTGTGATTAT-3' & 200 \\
\hline \multicolumn{4}{|l|}{ ETV6-RUNX1 } \\
\hline Subtype 1s1 & 5'-AGCCCCATCATGCACCCTCTGATCC-3' & 5'-GTGGTCGGCCAGCACCTCCACC-3' & 271 \\
\hline Subtype 1s2 & $\begin{array}{l}\text { 5'-GCAGAATTCCACTCCGTGGATTTCAA } \\
\text { ACAGTCC-3' }\end{array}$ & $\begin{array}{l}\text { 5'-AACGCCTCGCTCATCTTGCCTGG } \\
\text { GCTC-3' }\end{array}$ & 232 \\
\hline $\begin{array}{l}\text { Internal } \\
\text { control BL1 }\end{array}$ & 5'-GAGGGAAAAGCTTCACTCTG-3' & 5'-GCCGCAGCTGCTCCAGTTCA-3' & 200 \\
\hline \multicolumn{4}{|l|}{ AML1-ETO } \\
\hline AML1-ETO & 5'-GAGGGAAAAGCTTCACTCTG-3' & 5'-GCGAACTCTTTCTCCTATC-3' & 467 \\
\hline $\begin{array}{l}\text { Internal control } \\
\text { AML }\end{array}$ & 5'-GAGGGAAAAGCTTCACTCTG-3' & 5'-GCCGCAGCTGCTCCAGTTCA-3' & 192 \\
\hline \multicolumn{4}{|l|}{ CBFB-MYH11 } \\
\hline Subtype A & 5'-AGCTGCGTCTTCATCTCCTC-3' & 5'-CTGGATGGTATGGGCTGTCT-3' & 227 \\
\hline Subtype B & 5'-AGCTGCGTCTTCATCTCCTC-3' & 5'-CTGGATGGTATGGGCTGTCT-3' & 241 \\
\hline Subtype B & 5'-GTCTGTGTTATCTGGAAAGGCTG-3' & 5'-CGTACTGCTGGGTGAGGTTCT-3' & 620 \\
\hline Subtype C & 5'-GTCTGTGTTATCTGGAAAGGCTG-3' & 5'-CGTACTGCTGGGTGAGGTTCT-3' & 568 \\
\hline Subtype D & 5'-GTCTGTGTTATCTGGAAAGGCTG-3' & 5'-CGTACTGCTGGGTGAGGTTCT-3' & 775 \\
\hline $\begin{array}{l}\text { Internal control } \\
\text { CBF } \beta\end{array}$ & 5'-CTGGATGGTATGGGCTGTCT-3' & 5'-TAGGGTCTTGTTGTCTTCTTGC-3' & 230 \\
\hline
\end{tabular}

and Kaplan-Meier curves were used to analyze the effect of the miR-24 expression, gender, risk of relapse and risk classification (standard- and high-risk) on OS. $\mathrm{p}<0.05$ was considered to indicate a statistically significant result. All statistical analyses were performed using SPSS software, version 20.0 (SPSS, Inc., Chicago, IL, USA), GraphPad Prism software (version 5.0; GraphPad Software, Inc., USA) and STATA software, version 9.2 (StataCorp, College Station, TX, USA).

\section{Results}

General characteristics of the children with AL. We studied 111 children with ALL with a mean age of $7.73 \pm 4.91$ (mean $\pm \mathrm{SD}$ ) years and a median leukocyte count at diagnosis of 19,700 leukocytes $/ \mathrm{mm}^{3}$. The predominant gender was male with $63.06 \%$ while there were $36.94 \%$ female patients. These children $(63.96 \%)$ had a relapse of ALL at some time during their treatment. According to risk by age and leukocytes at diagnosis $43.24 \%$ of the children were in the age group of $1-9$ years, while $56.76 \%$ of the patients were $<1$ and $>9$ years of age at the time of the initial diagnosis.

Of the 111 cases with ALL examined by immunophenotype, B-lineage was the most frequently found $(83.78 \%)$. The majority $(83.78 \%)$ was cytomorphologically diagnosed as L1 (Table IV). Seven (6.31\%) cases of ALL presented with the BCR-ABL rearrangement; 1 case $(0.90 \%)$ the ETV6-RUNX1 rearrangement; while, $64(57.66 \%)$ showed none of the genetic rearrangements under study (BCR-ABL or ETV6-RUNX1 rearrangements). Thirty nine of the 111 patients with ALL were not considered for rearrangement analysis since analysis was not possible (Table IV).

Likewise, we also included 36 children with AML, who had a mean age of $8.102 \pm 4.79$ years, with a median of 34 , 550 leukocytes $/ \mathrm{mm}^{3}$ at diagnosis. There were $22(61.11 \%)$ 
Table IV. General characteristics and clinical data of the AL patients and healthy individuals.

\begin{tabular}{|c|c|c|c|c|}
\hline Variables & $\begin{array}{c}\text { ALL } \\
111(75.51)\end{array}$ & $\begin{array}{c}\text { AML } \\
36(24.49)\end{array}$ & $\begin{array}{l}\text { Healthy individuals } \\
100(100)\end{array}$ & P-value \\
\hline Age (years, mean \pm SD) & $7.73 \pm 4.91$ & $8.02 \pm 4.79$ & $10.21 \pm 5.53$ & $0.002^{\mathrm{d}}$ \\
\hline No. of leukocytes $/ \mathrm{mm}^{3}$ & $19,700(4,700-42,900)^{\mathrm{a}}$ & $34,550(9,350-68,000)^{\mathrm{a}}$ & $8,000(7,000-9,000)^{\mathrm{a}}$ & $<0.001^{\mathrm{d}}$ \\
\hline \multicolumn{5}{|l|}{ Gender } \\
\hline Female & $41(36.94)$ & $14(38.89)$ & $47(47.00)$ & \multirow[t]{2}{*}{0.317} \\
\hline Male & $70(63.06)$ & $22(61.11)$ & $53(53.00)$ & \\
\hline \multicolumn{5}{|l|}{ Status of participants } \\
\hline Alive & $42(37.84)$ & $13(36.11)$ & $100(100.00)$ & \multirow[t]{2}{*}{$1.00^{\mathrm{c}}$} \\
\hline Deceased & $69(62.16)$ & $23(63.89)$ & - & \\
\hline \multicolumn{5}{|l|}{$\begin{array}{l}\text { Risk by age and leukocytes } \\
\text { at diagnosis }\end{array}$} \\
\hline $\begin{array}{l}\text { Low-risk ( } 1-10 \text { years and } \\
\left.<50,000 \text { leukocytes } / \mathrm{mm}^{3}\right)\end{array}$ & $48(43.24)$ & $12(33.33)$ & - & \multirow[t]{2}{*}{$1.00^{\mathrm{c}}$} \\
\hline $\begin{array}{l}\text { High-risk }(<1 \text { and }>10 \text { years } \\
\left.\text { and }>50,000 \text { leukocytes } / \mathrm{mm}^{3}\right)\end{array}$ & $63(56.76)$ & $24(66.67)$ & - & \\
\hline \multicolumn{5}{|l|}{ Relapse during treatment } \\
\hline No & $40(36.04)$ & $17(47.22)$ & - & \multirow[b]{2}{*}{$0.244^{\mathrm{c}}$} \\
\hline Yes & $71(63.96)$ & $19(52.77)$ & - & \\
\hline \multicolumn{5}{|l|}{ Immunophenotype } \\
\hline B-lineage & $93(83.78)$ & - & - & \multirow[t]{3}{*}{-} \\
\hline T-lineage & $11(9.91)$ & - & - & \\
\hline B/T-lineage & $7(6.31)$ & - & - & \\
\hline \multicolumn{5}{|l|}{ FAB classification } \\
\hline $\mathrm{L} 1$ & $93(83.78)$ & - & - & \multirow[t]{6}{*}{-} \\
\hline L2 & $18(16.22)$ & - & - & \\
\hline M0 & - & $10(27.77)$ & - & \\
\hline M1 & - & $14(38.89)$ & - & \\
\hline M2 & - & $6(16.67)$ & - & \\
\hline M3 & - & $6(16.67)$ & - & \\
\hline \multicolumn{5}{|l|}{ Chromosomal translocations } \\
\hline ETV6-RUNX1 [t(12;21)] & $1(0.90)$ & - & - & \\
\hline BCR-ABL [t(9;22)] & $7(6.31)$ & - & - & \\
\hline AML1-ETO [t(8;21)] & - & $3(8.33)$ & - & \\
\hline CBFB-MYH11 [inv(16)] & - & $0(0.00)$ & - & - \\
\hline Negative & $64(57.66)$ & $22(61.11)$ & - & \\
\hline Not determined & $39(35.13)$ & $11(30.56)$ & - & \\
\hline miR-24 levels & $0.84(0.21-2.54)^{\mathrm{a}}$ & $4.22(2.08-8.22)^{\mathrm{a}}$ & $1.25(1.09-1.61)^{\mathrm{a}}$ & $<0.001^{\mathrm{d}}$ \\
\hline
\end{tabular}

Data are expressed as n (\%) unless indicated otherwise; ${ }^{a}$ median (percentiles 25-75). ${ }^{\mathrm{b}}$ Obtained by the Chi-square test. ${ }^{\mathrm{c}} \mathrm{p}$-value obtained between patients with ALL and AML. 'Significant $\mathrm{p}<0.05$. AL, acute leukemia; ALL, acute lymphoblastic leukemia AML, acute myeloid leukemia.

males and 14 (38.89\%) females. Twelve patients $(33.33 \%)$ were in the age group of 1-9 years. Twenty-four patients $(66.67 \%)$ were $<1$ and $>9$ years of age at the time of the initial diagnosis. Nineteen $(52.77 \%)$ of the patients with AML had a relapse at some time during their treatment (Table IV).

The FAB subtypes observed in the present study were M0-M3, with a preponderance of acute myeloblastic leukemia without maturation (FAB-M1, 38.89\%), followed by minimally differentiated acute myeloid leukemia (FAB-M0, 27.77\%). Adequate rearrangement analyses were obtained for $25(69.44 \%)$ of the patients with AML. Three $(8.33 \%)$ cases of AML presented with the AML1-ETO rearrangement; while, 22 (61.11\%) showed none of the genetic rearrangements under study (AML1-ETO or CBFB-MYH11 rearrangements). Eleven of the 36 patients with AML studied were not considered for rearrangement analysis since analysis was not possible (Table IV).

General characteristics of the healthy children. One-hundred healthy individuals (controls) were apparently included. In this group, the age range was $1-18$ years (mean $\pm \mathrm{SD}$, 


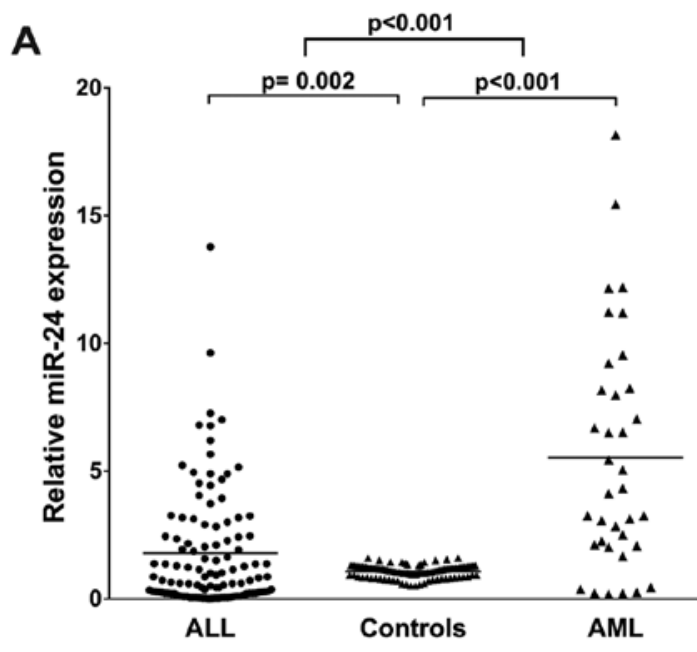

B
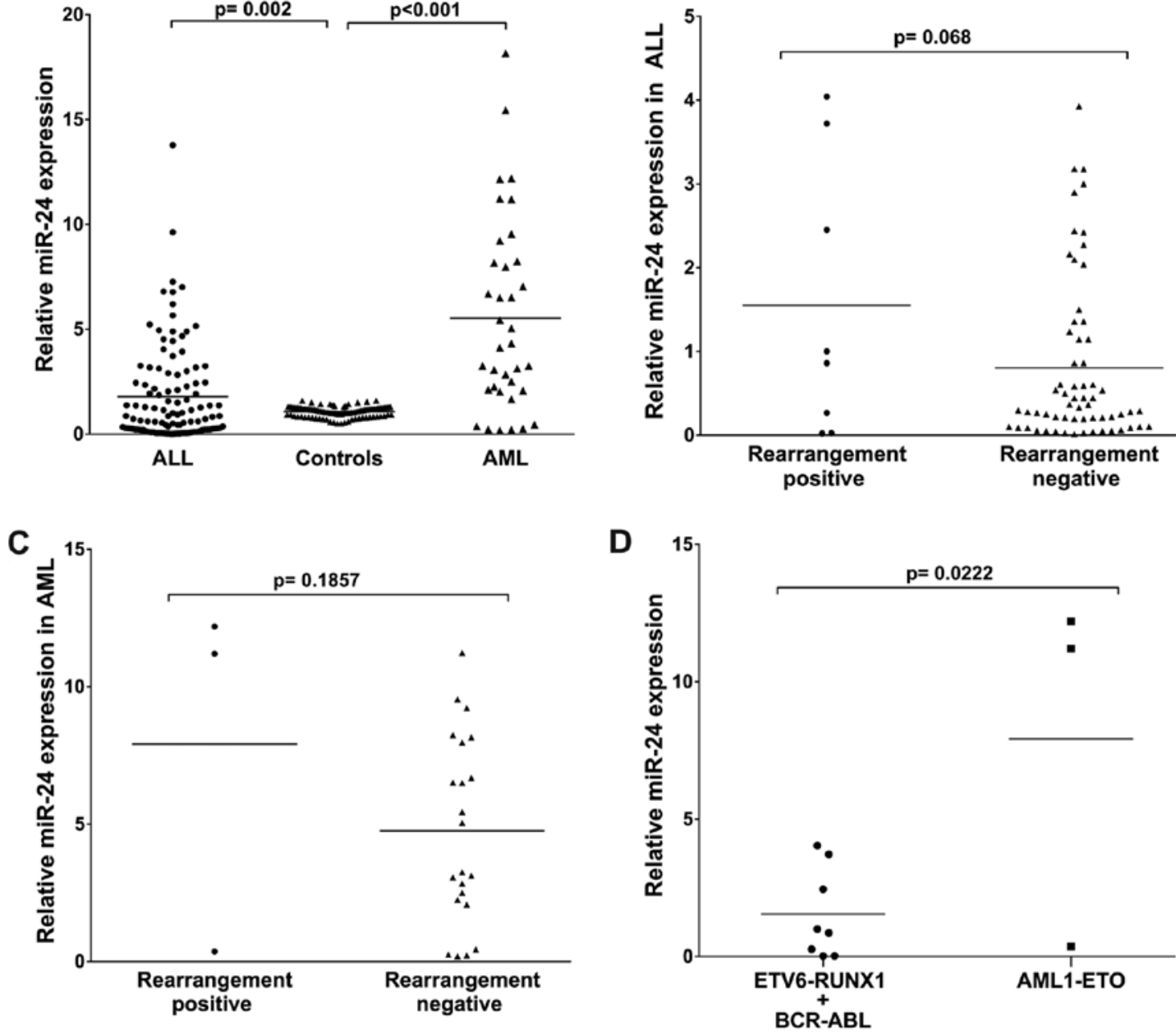

Figure 1. miR-24 expression in AL patients and healthy individuals. (A) The expression level of miR-24 in AML patients was significantly higher [median (25-75 percentiles), 4.22 (2.08-8.22); $\mathrm{p}<0.001]$. miR-24 in ALL patients was significantly lower [median (25-75 percentiles), 0.84 (0.21-2.54); $<<0.001$ ] (B) Levels of miR-24 expression in ALL patients with/without rearrangement were not significant ( $\mathrm{p}=0.068$ ). (C) Expression level of miR-24 in AML patients with/without rearrangement was not significant $(\mathrm{p}=0.185)$. (D) The expression level of miR-24 in AML1-ETO rearrangement-positive AML patients were significantly higher (median, 7.92; $\mathrm{p}=0.022$ ). While miR-24 in ETV6-RUNX1/BCR-ABL rearrangement-positive ALL patients was significantly lower (median, $1.55 ; \mathrm{p}=0.022)$. AL, acute leukemia; ALL, acute lymphoblastic leukemia; AML, acute myeloblastic leukemia.

$10.21 \pm 5.53$ years), and the leukocyte count was normal $\left(4-10 \times 10^{3}\right.$ leukocytes $/ \mathrm{mm}^{3}$; median 8,000$)$. In this group, 53 healthy individuals $(53.00 \%)$ were male and $47(47.00 \%)$ were female (Table IV). A significant difference could be observed in the age and the leukocyte count at diagnosis between the patients with AL and healthy individuals (Table IV).

miR-24 was differentially expressed in AML and ALL. To identify whether miR-24 was differentially expressed between the ALL and AML samples, we examined miR-24 levels in samples of the AL patients and the healthy individuals. The RNAs isolated were subjected to TaqMan RT-PCR analysis. The assays showed that the miR-24 levels were significantly higher $(4.22$ median, $\mathrm{p}<0.001)$ in the AML patients as compared with the healthy individuals. In turn, miR-24 in the ALL patients was significantly low (0.84 median, $\mathrm{p}=0.002)$. miR-24 expression in the AML patients was much higher than that in the ALL patients $(\mathrm{p}<0.001)$ (Table IV and Fig. 1A). These results suggest that upregulation of miR-24 expression may play a role in the progression of AML.
miR-24 expression in AL patients with/without rearrangement. We further quantitatively detected miR-24 expression in 111 cases of ALL and 36 cases of AML divided into two subtype groups: rearrangement-positive (ALL, 8; AML, 3) and rearrangement-negative (ALL, 64; AML, 22). The analysis showed no statistically significant difference between the positive and negative rearrangement patients $(\mathrm{p}=0.068$ for ALL and $\mathrm{p}=0.185$ for AML), (Fig. 1B and C).

Then, we compared miR-24 expression in patients according to ETV6-RUNX1/BCR-ABL vs. AML1-ETO rearrangement positivity and observed that miR-24 was significantly higher in the AML1-ETO-positive patients $(\mathrm{p}=0.022)$; the mean was 1.55-fold (ETV6-RUNX1/BCR-ABL) vs. 7.92fold (AML1-ETO) (Fig. 1D).

Risk of relapse based on the miR-24 expression and other risk factors. To evaluate the correlation between miR-24 expression and the risk of relapse to ALL, patients were divided into groups with downregulation and upregulation of miR-24 expression. The 75th percentile expression level of miR-24 
Table V. Association of miR-24 expression and clinical features with the risk of relapse to ALL.

\begin{tabular}{|c|c|c|c|c|c|c|c|c|c|}
\hline & \multirow{2}{*}{$\begin{array}{l}\text { Without } \\
\text { relapse } \\
\text { n }(\%)\end{array}$} & \multirow{2}{*}{$\begin{array}{c}\text { With } \\
\text { relapse } \\
\mathrm{n}(\%)\end{array}$} & \multirow[b]{2}{*}{ P-value } & \multicolumn{3}{|c|}{ Univariate analysis } & \multicolumn{3}{|c|}{ Multivariate analysis } \\
\hline & & & & OR & CI $95 \%$ & $\mathrm{P}$-value ${ }^{\mathrm{a}}$ & OR & CI $95 \%$ & P-value ${ }^{b}$ \\
\hline \multicolumn{10}{|l|}{ Gender } \\
\hline Female & $16(41.03)$ & $25(34.72)$ & 0.542 & 1.00 & & & & & \\
\hline Male & $23(58.97)$ & $47(65.28)$ & & 1.31 & $0.59-2.91$ & 0.512 & & & \\
\hline \multicolumn{10}{|l|}{ Immunophenotype } \\
\hline B-lineage & $36(92.31)$ & $57(79.17)$ & & 1.00 & & & & & \\
\hline T-lineage & $2(5.13)$ & $9(12.50)$ & 0.198 & 2.84 & $0.58-13.90$ & 0.197 & & & \\
\hline $\mathrm{B} / \mathrm{T}$-lineage & $1(2.56)$ & $6(8.33)$ & & 3.78 & $0.44-32.78$ & 0.226 & & & \\
\hline B-lineage & $36(92.31)$ & $57(79.17)$ & & 1.00 & & & & & \\
\hline $\mathrm{T}$-lineage $+\mathrm{B} / \mathrm{T}$-lineage & $3(7.69)$ & $15(20.83)$ & 0.105 & 3.15 & $0.85-11.67$ & 0.085 & & & \\
\hline \multicolumn{10}{|l|}{ FAB classification } \\
\hline \multicolumn{10}{|l|}{ ALL } \\
\hline L1 & $31(79.49)$ & $62(86.11)$ & & 1.60 & $0.57-4.46$ & 0.369 & & & \\
\hline $\mathrm{L} 2$ & $8(20.51)$ & $10(13.89)$ & 0.423 & 1.00 & & & & & \\
\hline \multicolumn{10}{|l|}{$\begin{array}{l}\text { Risk by age and leukocytes } \\
\text { at diagnosis }\end{array}$} \\
\hline $\begin{array}{l}\text { Low-risk }(1-10 \text { years and } \\
\left.<50,000 \text { leukocytes } / \mathrm{mm}^{3}\right)\end{array}$ & $27(69.23)$ & $21(29.17)$ & $<0.001^{\mathrm{c}}$ & 1.00 & & & & & \\
\hline $\begin{array}{l}\text { High-risk }(<1 \text { and }>10 \text { years } \\
\left.\text { and }>50,000 \text { leukocytes } / \mathrm{mm}^{3}\right)\end{array}$ & $12(30.77)$ & $51(70.83)$ & & 5.46 & $2.34-12.77$ & $<0.001^{\mathrm{c}}$ & 5.20 & $2.19-12.32$ & $<0.001^{\mathrm{c}}$ \\
\hline \multicolumn{10}{|l|}{ miR-24 levels } \\
\hline Downregulated & $27(69.23)$ & $34(47.22)$ & $0.030^{\mathrm{c}}$ & 1.00 & & & & & \\
\hline Upregulated & $12(30.77)$ & $38(52.78)$ & & 2.51 & $1.10-5.72$ & $0.028^{\mathrm{c}}$ & 2.27 & $1.94-5.51$ & $0.020^{\mathrm{c}}$ \\
\hline
\end{tabular}

(2.54-fold) was used as a cut-off point to divide all 111 patients with ALL into 2 groups. Those who expressed miR-24 at levels less than the cut-off value were assigned to the downregulation group $(n=61)$, and those with expression above the cut-off value were assigned to the upregulation group $(n=50)$.

In a logistic regression analysis, an association was observed between miR-24 expression and the risk of relapse of ALL $(p<0.05)$. It was observed that those patients with upexpression of miR-24, showed a significant increase in the risk of relapse to $\mathrm{ALL}(\mathrm{OR}=2.51,95 \% \mathrm{CI} 1.10-5.72, \mathrm{p}=0.028)$ compared to those patients who had downexpression of miR-24 expression (Table V). We also observed that individuals $<1$ and $>10$ years of age with $>50,000$ leukocytes $/ \mathrm{mm}^{3}$ (high-risk) had a 5.46 fold $(95 \%$ CI $2.34-12.77$, p $\leq 0.001)$ increased risk to have relapsed compared to individuals between 1-10 years with $<50,000$ leukocytes $/ \mathrm{mm}^{3}$ (low-risk) (Table V).

Similarly to what was carried out with patients with ALL, the patients with AML were divided in subgroups according to downexpression and upexpression $[<$ or $>75$ th percentile expression level of miR-24 (8.22-fold)]: downexpression group $(n=18)$ and upexpression group $(n=18)$. We also examined the relationship between miR-24 expression levels and the risk of relapse to AML. We observed a significant correla- tion between miR-24 expression levels and risk of relapse (OR=7.00, 95\% CI 1.59-30.79, $\mathrm{p}=0.010)$, (Table VI). These data suggest that upregulation of miR-24 expression may have an important role in the relapse of the disease.

Expression of miR-24 is associated with unfavorable prognosis in AL patients. The relationship between survival and gender was also calculated. We observed that males had a poorer OS compared to females (log-rank test; $\mathrm{p}=0.034$ for ALL, Fig. 2A). In AML the Kaplan-Meier survival curves showed no significant association between gender and survival, although a reduction in survival among men and women was observed (log-rank test; $\mathrm{p}=0.323$; Fig. 3A).

Likewise, individuals $<1$ and $>10$ years of age with $>50,000$ leukocytes $/ \mathrm{mm}^{3}$ (high-risk) had a poor survival rate compared with those patients between 1-10 years of age with $<50,000$ leukocytes $/ \mathrm{mm}^{3}$ (Fig. 2B; log-rank test; $\mathrm{p}<0.001$ for ALL and Fig. 3B; log-rank test; $\mathrm{p}=0.031$ for AML). A different rate of OS was evident between the individuals with and without relapse of AL (Fig. 2C; log-rank test; $\mathrm{p}<0.001$ for ALL and Fig. 3C; log-rank test; $p=0.015$ for AML).

The association between miR-24 expression and survival of AL patients was investigated. We observed that ALL patients 
Table VI. Association of the miR-24 expression and clinical features with risk of relapse to AML.

\begin{tabular}{|c|c|c|c|c|c|c|c|c|c|}
\hline & \multirow{2}{*}{$\begin{array}{l}\text { Without } \\
\text { relapse } \\
\mathrm{n}(\%)\end{array}$} & \multirow{2}{*}{$\begin{array}{l}\text { With } \\
\text { relapse } \\
\mathrm{n}(\%)\end{array}$} & \multirow[b]{2}{*}{ P-value } & \multicolumn{3}{|c|}{ Univariate analysis } & \multicolumn{3}{|c|}{ Multivariate analysis } \\
\hline & & & & OR & CI $95 \%$ & P-value ${ }^{a}$ & OR & CI $95 \%$ & P-value \\
\hline \multicolumn{10}{|l|}{ Gender } \\
\hline Female & $7(43.75)$ & $7(35.00)$ & 0.734 & 1.00 & & & & & \\
\hline Male & $9(56.25)$ & $13(65.00)$ & & 1.44 & $0.37-5.57$ & 0.593 & & & \\
\hline \multicolumn{10}{|l|}{ FAB classification } \\
\hline M0 & $5(31.25)$ & $5(25.00)$ & & 0.73 & $0.17-3.17$ & 0.678 & & & \\
\hline M1 & $7(50.00)$ & $5(30.00)$ & 0.460 & 0.42 & $0.10-1.76$ & 0.240 & & & \\
\hline M2 & $2(6.25)$ & $6(15.00)$ & & 3.00 & $0.51-17.49$ & 0.222 & & & \\
\hline M3 & $2(12.50)$ & $4(20.00)$ & & 1.00 & & & & & \\
\hline \multicolumn{10}{|l|}{$\begin{array}{l}\text { Risk by age and leukocytes } \\
\text { at diagnosis }\end{array}$} \\
\hline $\begin{array}{l}\text { Low-risk (1-10 years and } \\
\left.<50,000 \text { leukocytes } / \mathrm{mm}^{3}\right)\end{array}$ & $12(75.00)$ & $7(35.00)$ & $0.023^{\mathrm{c}}$ & 1.00 & & & & & \\
\hline $\begin{array}{l}\text { High-risk }(<1 \text { and }>10 \text { years } \\
\left.\text { and }>50,000 \text { leukocytes } / \mathrm{mm}^{3}\right)\end{array}$ & $4(25.00)$ & $13(65.00)$ & & 5.57 & $1.29-23.93$ & $0.021^{\mathrm{c}}$ & 8.38 & $1.39-50.56$ & $0.020^{\mathrm{c}}$ \\
\hline \multicolumn{10}{|l|}{ miR-24 levels } \\
\hline Downregulated & $12(75.00)$ & $6(30.00)$ & $0.018^{\mathrm{c}}$ & 1.00 & & & & & \\
\hline Upregulated & $4(25.00)$ & $14(70.00)$ & & 7.00 & $1.59-30.79$ & $0.010^{\mathrm{c}}$ & 10.20 & $1.71-60.87$ & $0.011^{\mathrm{c}}$ \\
\hline
\end{tabular}

OR, odds ratio; CI, confidence interval; ${ }^{a} \mathrm{p}$-value was obtained by logistic regression analysis, taking reference to female, M3, 1-10 years, $<50,000$ leukocytes $/ \mathrm{mm}^{3}$ (low-risk) and downregulated levels of miR-24. ${ }^{\mathrm{b}} \mathrm{p}$-value was obtained by multivariate logistic regression analysis. ${ }^{\mathrm{c}}$ Significant $\mathrm{p}<0.05$. AML, acute myeloblastic leukemia.

with high miR-24 expression tend to have shorter OS than those with low miR-24 (Fig. 2D; log-rank test; $p=0.001$ for ALL and Fig. 3D; log-rank test; $p=0.018$ for AML). During the followup period, 69 of the 111 patients with ALL (62.16\%) and 23 of the 36 patients with AML (63.89\%) had died (Table IV). In addition, the univariate and multivariate analyses performed showed that miR-24 expression is an independent prognostic factor for AL (Tables V and VI).

\section{Discussion}

Acute leukemias (ALs) are the most frequent type of childhood cancers (2). In spite of the development of advanced therapeutic strategies, the prognosis of patients with this type of cancer varies significantly and is hard to predict; therefore knowledge of the prognosis is vital since some patients with AL have different responses to the same therapy (27). Therefore, it is critical to identify biomarkers for the early identification of patients with a high-risk of treatment failures, in order to modify therapeutic methods for improving the overall survival (OS) of patients with AL.

miR-24 is a tumor-suppressor among the miRNAs that are consistently upregulated during terminal differentiation. miR-24 is expressed in a cyclical manner and takes part in maintaining and regulating proper cell cycle progression and apoptosis $(13,15)$. Overexpression of miR-24 in liver, gastric, prostate and cervical cancer cell lines was found to protects these cells from apoptosis whereas knockdown of miR-24 turns differentiated cells into a proliferation state and sensi- tizes them to apoptosis $(13,15)$. Yet the role of miR-24 in AL samples is poorly understood. We investigated the expression of miR-24 in samples of AL patients and detected its relationships with clinical parameters.

In the present study, we observed that miR-24 expression was significantly increased in both AML and ALL patients $(\mathrm{p}<0.001)$. This phenomenon was consistent with previous publications, where it was noted that miR-24 promotes the survival of hematopoietic progenitors $(16,28)$.

A previous study has shown miR-24 to have an increased expression in AML and a decreased expression in ALL (28). For a more comprehensive insight into the clinical value of miR-24, in the present study we performed a logistic regression analysis to investigate its association with the clinical features of AL patients. Our data proved that miR-24 expression was significantly higher in AL patients compared with that in apparently healthy individuals $(\mathrm{p}<0.001)$. We observed a statistically significant association between the expression of miR-24 and the risk of $\mathrm{AL}(\mathrm{OR}=2.51,95 \%$ CI 1.10-5.72, $\mathrm{p}=0.028$ for ALL and OR=7.00, 95\% CI 1.59-30.79, $\mathrm{p}=0.010$ for AML). In addition, miR-24 expression, was associated with risk of relapse of leukemia $(\mathrm{p}<0.05)$. This suggests that the regulation of miR-24 expression, and the high association with the risk of relapse $(\mathrm{p}<0.05)$ may be a factor that led to $>50 \%$ of deaths in the patients with AL included in the present study.

Moreover, it was reported that miRNA expression is correlated with cytogenetic and molecular subtypes of AL [i.e., with $\mathrm{t}(8 ; 21), \mathrm{t}(15 ; 17)$, inv(16), NPM1 and CEBPA mutations] (8). Notably, two from our cases with $t(8 ; 21)$ rearrangement 

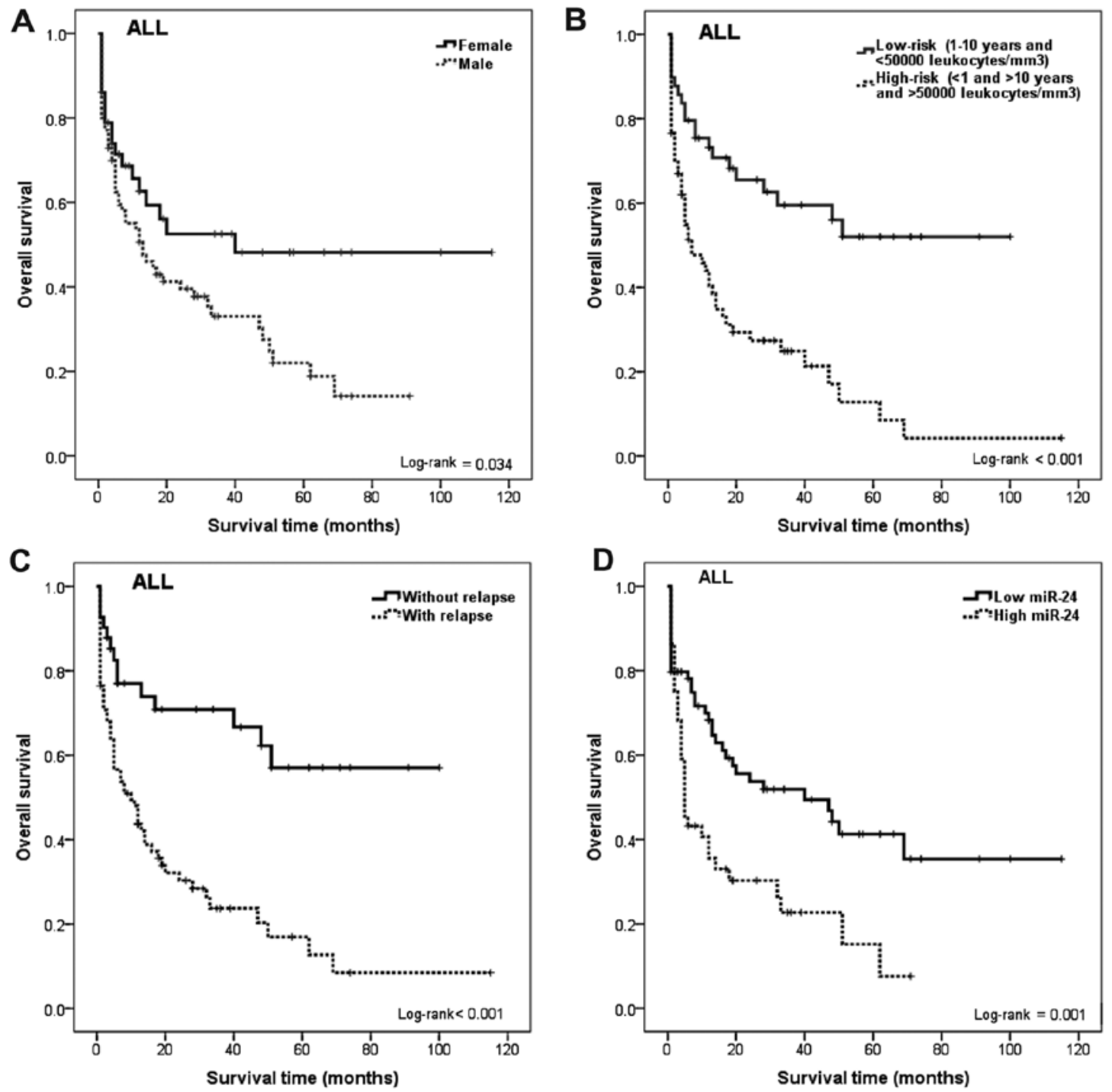

Figure 2. Kaplan-Meier curves for overall survival time influence of gender, risk by age and leukocyte count at diagnosis, relapse and miR-24 expression of ALL patients. (A) OS in females and males with ALL. Significantly shorter OS for males than female patients was noted (p=0.034). (B) OS between patients with low risk (1-10 years of age and $<50,000$ leukocytes $/ \mathrm{mm}^{3}$ ) and high risk $\left(<1\right.$ and $>10$ years of age and $>50,000$ leukocytes $\left./ \mathrm{mm}^{3}\right)$. Significantly longer OS for patients with a low risk than patients with high-risk was noted $(\mathrm{p}<0.001)$. (C) OS between patients with and without relapse. Significantly shorter OS for patients with relapse than patients without relapse was noted ( $\mathrm{p}<0.001)$. (D) OS was significantly shorter for patients with high miR-24 expression than for those with low miR-24 expression ( $\mathrm{p}=0.001$ ). ALL, acute lymphoblastic leukemia; OS, overall survival.

presented high expression of miR-24 when compared with others rearrangements (ETV6-RUNX1/BCR-ABL), which is similar to previous findings (8,28-30).

In many studies, age, gender and white cell count at diagnosis have been shown to be a consistently strong prognostic factors in childhood AL. Patients < 1 year of age have higher relapse rates compared with others ages as reported in various studies; this feature also retained its significance in this study. Patients in the age group of 1-10 years (low-risk) had the best prognosis, whereas patients $<1$ and $>9$ years of age (high-risk) showed the worst prognosis $(\mathrm{OR}=5.46,95 \%$ CI 2.34-12.77, $\mathrm{p} \leq 0.001$ for ALL and $\mathrm{OR}=5.57,95 \%$ CI 1.29-23.93, $\mathrm{p}=0.021$ for $\mathrm{AML}$ ), which agrees with previous studies (17,31-33). The relationship between white cell count at diagnosis (WBC) and prognosis has been firmly established in many studies of childhood AL (17,30-33) and confirmed in the present study. WBC >50,000 leukocytes/ $\mathrm{mm}^{3}$ (high-risk) has been shown to be an adverse risk factor in childhood AL. This value has been proposed as the value by which to define patients with a poor prognosis by the National Cancer Institute sponsored workshop (20).

In the multivariate analysis, for patients with miR-24 expression, OR estimates retained their significance $(\mathrm{p}<0.05)$ in the presence of other prognostic factors, which also influenced AL outcome (age, gender and risk by age and leukocytes at diagnosis), which suggests that miR-24 is an independent prognostic marker for AL. More importantly, we proved that miR-24 expression was significantly associated with OS of patients with AL. In support of this, Kaplan-Meier analysis of OS showed that patients with high miR-24 expression tended to have a significantly shorter OS compared with patients with low expression (log-rank $\mathrm{p}<0.05$ ), indicating that high miR-24 expression is a marker of poor prognosis for patients with AL. Thus, miR-24 could be used as molecular prognostic marker in addition to known prognostic indicators, in order to identify patients who are more likely to have a higher risk of death, thus, should receive more aggressive treatment. 

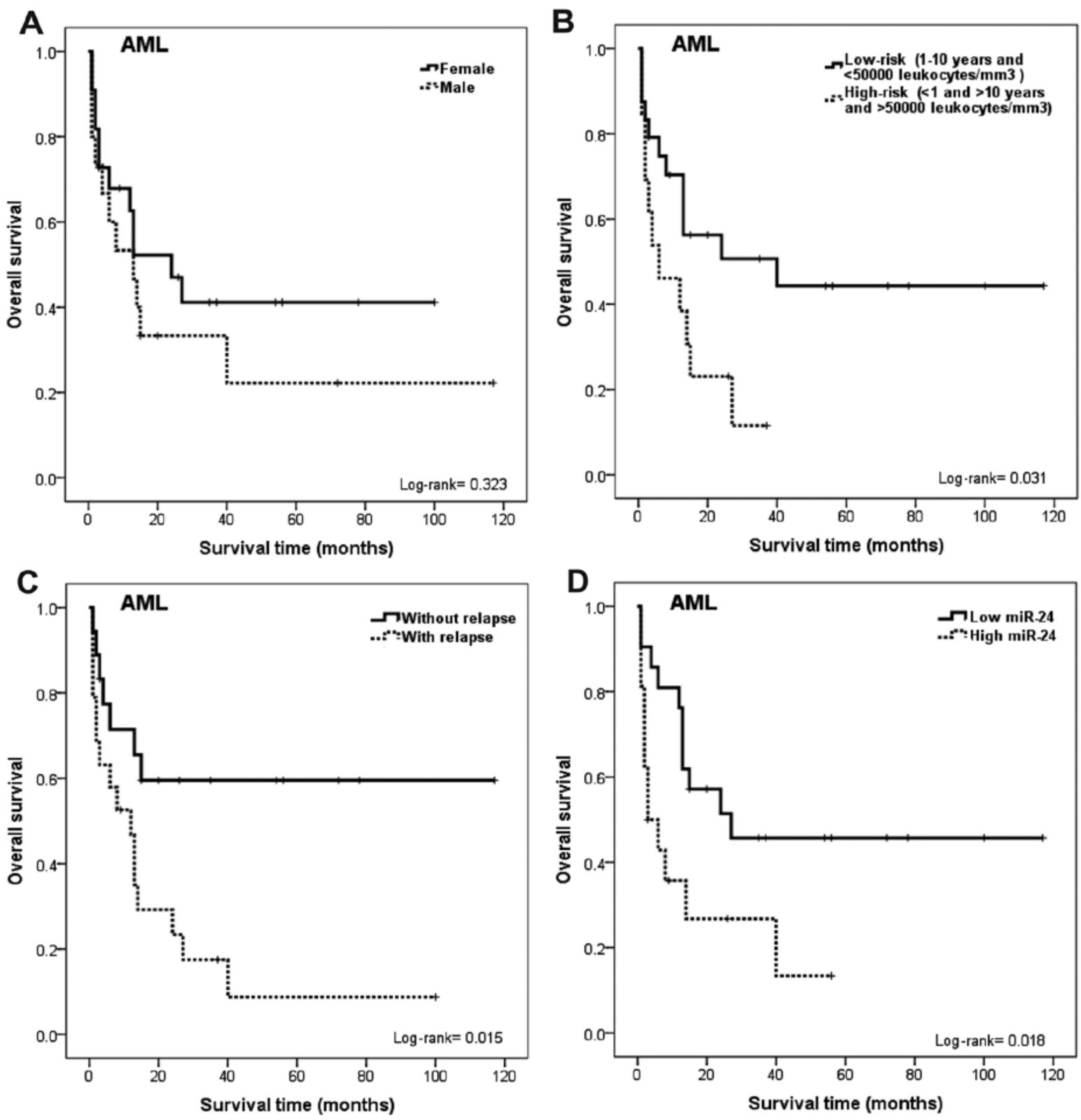

Figure 3. Kaplan-Meier curves for overall survival time considering the influence of gender, risk by age and leukocyte count at diagnosis, relapse and miR-24 expression of AML patients. (A) OS in females and males with AML. Shorter OS for male than female patients was noted (although it was not statistically significant, $\mathrm{p}=0.323)$. (B) OS between patients with low-risk (1-10 years of age and $<50,000$ leukocytes $\left./ \mathrm{mm}^{3}\right)$ and high-risk $(<1$ and $>10$ years of age and $>50,000$ leukocytes $\left./ \mathrm{mm}^{3}\right)$. Significantly longer OS for patients with a low-risk than patients with high-risk $(\mathrm{p}=0.031)$. (C) OS between patients with and without relapse. Significantly shorter OS for patients with relapse than patients without relapse was noted $(\mathrm{p}=0.015)$. (D) OS significantly shorter for patients with high miR-24 expression than for those with low miR-24 expression ( $\mathrm{p}=0.018$ ). AML, acute myeloblastic leukemia; OS, overall survival.

In conclusion, our data indicated that miR-24 upregulation was associated with poor prognosis in AL. miR-24 was identified for the first time as an independent marker for predicting the clinical outcome of AL patients. Nevertheless, our data generate novel hypotheses regarding the role of miR-24 expression in the risk and relapse of AL and an impact on survival of AL patients, which will have to be confirmed in independent studies.

\section{Acknowledgements}

Y.G.G. and J.O.N were recipients of fellowships from the Programa de Apoyo a los Estudios de Posgrado, Universidad Nacional Autónoma de Mexico (PAEP-UNAM).

\section{References}

1. Dorantes-Acosta E and Pelayo R: Lineage switching in acute leukemias: A consequence of stem cell plasticity? Bone Marrow: 406796, 2012. http://dx.doi.org/10.1155/2012/406796.

2. Daniel-Cravioto A, Gonzalez-Bonilla CR, Mejia-Arangure JM, Perez-Saldivar ML, Fajardo-Gutierrez A, Jimenez-Hernandez E, Hernandez-Serrano M and Bekker-Mendez VC: Genetic rearrangement MLL/AF4 is most frequent in children with acute lymphoblastic leukemias in Mexico City. Leuk Lymphoma 50: 1352-1360, 2009.

3. Pérez-Saldivar ML, Fajardo-Gutiérrez A, Bernáldez-Ríos R, et al: Childhood acute leukemias are frequent in Mexico City: descriptive epidemiology. BMC Cancer 11: 355, 2011.

4. Bartel DP: MicroRNAs: Genomics, biogenesis, mechanism, and function. Cell 116: 281-297, 2004.

5. Calin GA and Croce CM: MicroRNA signatures in human cancers. Nat Rev Cancer 6: 857-866, 2006. 
6. Calin GA, Ferracin M, Cimmino A, et al: A MicroRNA signature associated with prognosis and progression in chronic lymphocytic leukemia. N Engl J Med 353: 1793-1801, 2005.

7. Garzon R, Volinia S, Liu CG, et al: MicroRNA signatures associated with cytogenetics and prognosis in acute myeloid leukemia. Blood 111: 3183-3189, 2008.

8. Jongen-Lavrencic M, Sun SM, Dijkstra MK, Valk PJ and Löwenberg B: MicroRNA expression profiling in relation to the genetic heterogeneity of acute myeloid leukemia. Blood 111: 5078-5085, 2008.

9. Georgantas RW III, Hildreth R, Morisot S, Alder J, Liu CG, Heimfeld S, Calin GA, Croce CM and Civin CI: CD34 ${ }^{+}$hematopoietic stem-progenitor cell microRNA expression and function: a circuit diagram of differentiation control. Proc Natl Acad Sci USA 104: 2750-2755, 2007

10. Xiao C, Calado DP, Galler G, Thai TH, Patterson HC, Wang J, Rajewsky N, Bender TP and Rajewsky K: miR-150 controls B cell differentiation by targeting the transcription factor $\mathrm{c}-\mathrm{Myb}$ Cell 131: 146-159, 2007.

11. Ben-Ami O, Pencovich N, Lotem J, Levanon D and Groner Y: A regulatory interplay between miR-27a and Runx1 during megakaryopoiesis. Proc Natl Acad Sci USA 106: 238-243, 2009.

12. Wang Q, Huang Z, Xue H, Jin C, Ju XL, Han JD and Chen YG: MicroRNA miR-24 inhibits erythropoiesis by targeting activin type I receptor ALK4. Blood 111: 588-595, 2008.

13. Qin W, Shi Y, Zhao B, Yao C, Jin L, Ma J and Jin Y: miR-24 regulates apoptosis by targeting the open reading frame (ORF) region of FAF1 in cancer cells. PLoS One 5: e9429, 2010.

14. Cheng AM, Byrom MW, Shelton J and Ford LP: Antisense inhibition of human miRNAs and indications for an involvement of miRNA in cell growth and apoptosis. Nucleic Acids Res 33: 1290-1297, 2005.

15. Lal A, Navarro F, Maher CA, et al: miR-24 inhibits cell proliferation by targeting E2F2, MYC, and other cell-cycle genes via binding to 'seedless' 3 'UTR microRNA recognition elements. Mol Cell 35: 610-625, 2009.

16. Nguyen T, Rich A and Dahl R: miR-24 promotes the survival of hematopoietic cells. PLoS One 8: e55406, 2013.

17. Gómez-Gómez Y, Organista-Nava J, Saavedra-Herrera MV, Rivera-Ramírez AB, Terán-Porcayo MA, Del Carmen AlarcónRomero L, Illades-Aguiar B and Leyva-Vázquez MA: Survival and risk of relapse of acute lymphoblastic leukemia in a Mexican population is affected by dihydrofolate reductase gene polymorphisms. Exp Ther Med 3: 665-672, 2012.

18. Seguro-popular: Secretaria de Salud/Seguro Popular A, 2007. Available at: http://seguropopular.col.gob.mx/segpop/. (Accessed May, 2009).

19. Reiter A, Schrappe M, Ludwig WD, et al: Chemotherapy in 998 unselected childhood acute lymphoblastic leukemia patients. Results and conclusions of the multicenter trial ALL-BFM 86 Blood 84: 3122-3133, 1994

20. Smith M, Arthur D, Camitta B, et al: Uniform approach to risk classification and treatment assignment for children with acute lymphoblastic leukemia. J Clin Oncol 14: 18-24, 1996.

21. Chomczynski P and Sacchi N: Single-step method of RNA isolation by acid guanidinium thiocyanate-phenol-chloroform extraction. Anal Biochem 162: 156-159, 1987.
22. Shtivelman E, Lifshitz B, Gale RP and Canaani E: Fused transcript of abl and bcr genes in chronic myelogenous leukaemia. Nature 315: 550-554, 1985

23. van der Feltz MJ, Shivji MK, Allen PB, Heisterkamp N, Groffen J and Wiedemann LM: Nucleotide sequence of both reciprocal translocation junction regions in a patient with $\mathrm{Ph}$ positive acute lymphoblastic leukaemia, with a breakpoint within the first intron of the $B C R$ gene. Nucleic Acids Res 17: 1-10, 1989.

24. Kozu T, Miyoshi H, Shimizu K, Maseki N, Kaneko Y, Asou H, Kamada N and Ohki M: Junctions of the AML1/MTG8(ETO) fusion are constant in $\mathrm{t}(8 ; 21)$ acute myeloid leukemia detected by reverse transcription polymerase chain reaction. Blood 82 : 1270-1276, 1993

25. Harbott J, Viehmann S, Borkhardt A, Henze G and Lampert F: Incidence of TEL/AML1 fusion gene analyzed consecutively in children with acute lymphoblastic leukemia in relapse. Blood 90: 4933-4937, 1997.

26. Claxton DF, Liu P, Hsu HB, Marlton P, Hester J, Collins F, Deisseroth AB, Rowley JD and Siciliano MJ: Detection of fusion transcripts generated by the inversion 16 chromosome in acute myelogenous leukemia. Blood 83: 1750-1756, 1994.

27. Dulucq S, St-Onge G, Gagné V, Ansari M, Sinnett D, Labuda D, Moghrabi A and Krajinovic M: DNA variants in the dihydrofolate reductase gene and outcome in childhood ALL. Blood 111: 3692-3700, 2008.

28. Mi S, Lu J, Sun M, et al: MicroRNA expression signatures accurately discriminate acute lymphoblastic leukemia from acute myeloid leukemia. Proc Natl Acad Sci USA 104: 19971-19976, 2007.

29. Daschkey S, Röttgers S, Giri A, Bradtke J, Teigler-Schlegel A, Meister G, Borkhardt A and Landgraf P: MicroRNAs distinguish cytogenetic subgroups in pediatric AML and contribute to complex regulatory networks in AML-relevant pathways. PLoS One 8: e56334, 2013

30. Zaidi SK, Dowdy CR, van Wijnen AJ, Lian JB, Raza A, Stein JL, Croce CM and Stein GS: Altered Runx1 subnuclear targeting enhances myeloid cell proliferation and blocks differentiation by activating a miR-24/MKP-7/MAPK network. Cancer Res 69: 8249-8255, 2009

31. Organista-Nava J, Gómez-Gómez Y, Saavedra-Herrera MV, Rivera-Ramírez AB, Terán-Porcayo MA, Alarcón-Romero LC, Illades-Aguiar B and Leyva-Vázquez MA: Polymorphisms of the $\gamma$-glutamyl hydrolase gene and risk of relapse to acute lymphoblastic leukemia in Mexico. Leuk Res 34: 728-732, 2010.

32. Ng SM, Lin HP, Ariffin WA, Zainab AK, Lam SK and Chan LL: Age, sex, haemoglobin level, and white cell count at diagnosis are important prognostic factors in children with acute lymphoblastic leukemia treated with BFM-type protocol. J Trop Pediatr 46: 338-343, 2000

33. Leyva-Vázquez MA, Organista-Nava J, Gómez-Gómez Y, Contreras-Quiroz A, Flores-Alfaro E and Illades-Aguiar B: Polymorphism G80A in the reduced folate carrier gene and its relationship to survival and risk of relapse in acute lymphoblastic leukemia. J Investig Med 60: 1064-1067, 2012. 